\title{
Northeast Atlantic breakup volcanism and consequences for Paleogene climate change - MagellanPlus Workshop report
}

\author{
Christian Berndt $^{1}$, Sverre Planke ${ }^{2,3}$, Damon Teagle $^{4}$, Ritske Huismans ${ }^{5}$, Trond Torsvik ${ }^{2}$, Joost Frieling ${ }^{6}$, \\ Morgan T. Jones ${ }^{2}$, Dougal A. Jerram ${ }^{2,7}$, Christian Tegner ${ }^{8}$, Jan Inge Faleide ${ }^{2}$, Helen Coxall ${ }^{9}$, and \\ Wei-Li Hong ${ }^{10}$ \\ ${ }^{1}$ GEOMAR, 24218 Kiel, Germany \\ ${ }^{2}$ Centre for Earth Evolution and Dynamics, Department of Geosciences, \\ University of Oslo, 0315, Oslo, Norway \\ ${ }^{3}$ VBPR, 0349 Oslo, Norway \\ ${ }^{4}$ School of Ocean and Earth Sciences, University of Southampton, SO14 3ZH Southampton, UK \\ ${ }^{5}$ Department of Earth Science, University of Bergen, 5007 Bergen, Norway \\ ${ }^{6}$ Department of Earth Sciences, Utrecht University, 3584 Utrecht, the Netherlands \\ ${ }^{7}$ DougalEARTH Ltd, B91 3NU Solihull, UK \\ ${ }^{8}$ Department of Geoscience, University of Aarhus, 8000 Aarhus, Denmark \\ ${ }^{9}$ Department of Geological Sciences, Stockholm University, 10691 Stockholm, Sweden \\ ${ }^{10}$ Geological Survey of Norway, 7040 Trondheim, Norway \\ Correspondence: Christian Berndt (cberndt@geomar.de)
}

Received: 24 June 2019 - Revised: 22 October 2019 - Accepted: 28 October 2019 - Published: 2 December 2019

\begin{abstract}
The northeast Atlantic encompasses archetypal examples of volcanic rifted margins. Twenty-five years after the last ODP (Ocean Drilling Program) leg on these volcanic margins, the reasons for excess melting are still disputed with at least three competing hypotheses being discussed. We are proposing a new drilling campaign that will constrain the timing, rates of volcanism, and vertical movements of rifted margins. This will allow us to parameterise geodynamic models that can distinguish between the hypotheses. Furthermore, the drilling-derived data will help us to understand the role of breakup magmatism as a potential driver for the Palaeocene-Eocene thermal maximum (PETM) and its influence on the oceanographic circulation in the earliest phase of the northeast Atlantic Ocean formation. Tackling these questions with a new drilling campaign in the northeast Atlantic region will advance our understanding of the long-term interactions between tectonics, volcanism, oceanography, and climate and the functioning of subpolar northern ecosystems and climate during intervals of extreme warmth.
\end{abstract}

\section{Introduction}

The formation of continental margins is accompanied by a broad spectrum of magmatic activity ranging from little volcanism to the emplacement of a large igneous province (LIP) (Fig. 1). The reasons for this variability in magmatism are still disputed despite it being of large societal and economic importance. DSDP (Deep Sea Drilling Project) Legs 38 and 81 investigated the nature of the continental margins around the northeast Atlantic in 1974. ODP (Ocean Drilling Program) Legs 104, 152, and 163 in 1985, 1993, and 1995 established that volcanism plays a major role in continental breakup and instituted the concept of volcanic passive margins (Coffin and Eldholm, 1992; Eldholm et al., 2000). Breakup volcanism has since been identified as a major short-term climate driver that may have played a role in several mass extinctions (Eldholm and Thomas, 1993; Svensen et al., 2004, 2007). Magmatic intrusions can be of particu- 
lar importance as they may have the potential to release large amounts of greenhouse gases through contact metamorphism in a very short time (Berndt et al., 2016), and it remains plausible that the magmatism associated with the breakup of the northeast Atlantic triggered the Palaeocene-Eocene thermal maximum (PETM) (Svensen et al., 2004; Minshull et al., 2016). The subsequent long-term tectonic evolution of the northeast Atlantic through the Paleogene and Neogene created an ocean gateway linking the Arctic Ocean to global circulation that is likely to have played a significant role in causing, or amplifying, environmental changes through its influence on ocean circulation (Laughton, 1975; Miller and Tucholke, 1983; Jakobsson et al., 2007; Coxall et al., 2018).

The underlying geodynamic processes that control the rifted margin structure are relatively well understood (e.g. Huismans and Beaumont, 2011). However, what drives and controls the degree of breakup magmatism remains disputed, despite the potential for breakup magmatism to affect tectonic deformation and to lead to abrupt climate change. The development of the concept of seismic volcanostratigraphy (Planke et al., 2000) represents a breakthrough that could lead to progress in understanding these processes. Seismic volcanostratigraphy is an interpretive framework that relates particular seismic facies to various volcanic emplacement environments, which has enabled large areas of volcanic margins to be interpreted from remote seismic data (e.g. Abdelmalak et al., 2016, 2019). This framework, developed through the joint analysis of results from ODP Legs 104 and 152 and large amounts of seismic data, enables seismic data to be used to infer the duration of volcanism, emplacement rate changes, subsidence history, and other aspects of volcanic margin formation that are tied to both the underlying geodynamic drivers of rift volcanism and the impact of that volcanism on the hydrosphere and atmosphere. Since 1996 there has been no dedicated scientific drilling leg to test the predictions that stem from seismic volcanostratigraphy and new seismic and potential field data (e.g. Abdelmalak et al., 2016; Planke et al., 2017), and thus important hypotheses remain untested that could be assessed with targeted drilling sites. These include the suggestion that northeast Atlantic breakup volcanism was short-lived enough to be a viable driver for the rapid early Paleogene climate change event and, by extension, other environmental crises throughout Earth's history.

In May 2018, we convened a MagellanPlus IODP-ICDP (International Ocean Discovery Program-International Continental Scientific Drilling Program) drilling workshop at GEOMAR, Germany, to develop new drilling proposals that would lead to an improved understanding of the nature of breakup volcanism and evolving Atlantic-Arctic gateways. This includes, for example, the question as to whether a link exists between hydrothermal venting of greenhouse gases formed by the heating of organic-rich sedimentary rocks by igneous intrusions and global negative carbon isotope excursions, such as those observed during the PETM. This would require dating the respective intrusions and the hydrothermal vent structures, sampling the Paleogene sediments and ash layers in high resolution, and constraining the extent of breakup-related volcanic successions and environments in which they were emplaced. Also required is an improved understanding of the nature of volcanic seismic facies units and whether they represent specific environmental conditions during the emplacement of the breakup volcanic extrusive successions and if they can be used to decipher the interaction of magmatic processes and (local) relative sea level changes. The early oceanic basins were likely restricted by igneous deposits which, at best, only allowed shallow surface water exchange with the Arctic Ocean and North Sea until the Miocene, after which the Greenland-Scotland Ridge and Fram Strait had deepened to allow for the exchange of cold dense waters, an important prerequisite for a deep Atlantic overturning circulation. Testing this hypothesis requires the coring of Eocene-Neogene sediments overlying the volcanic basement to produce a chronologic and palaeoenvironmental framework that constrains deep and surface water properties, including basin ventilation state and surface salinities.

Since the mid-1990s, major advances in seismic imaging, e.g. the development of three-dimensional seismic techniques and broadband processing, and their applications to volcanic provinces by the industry delineated the youngest, best-imaged, and most-accessible sub-surface structures. As a result, we identified a number of suitable IODP and ICDP drilling targets offshore in the northeast and northwest Atlantic and onshore in northern Denmark. Drilling these targets will allow us to better establish the sequence of events leading to the construction of the breakup-related igneous complexes. Furthermore, the drilling of the different seismic facies units would provide the ground truth about the predictions of seismic volcanostratigraphy. Together this information will constitute a step increase in our understanding of the underlying geodynamic processes of continental breakup and initial seafloor spreading, breakup-related magmatism, and the consequences of these processes on global environments.

\section{Globally relevant aspects of studying breakup volcanism}

\subsection{Fundamental tectonomagmatic processes controlling breakup volcanism}

The mechanism responsible for rift-related anomalous excess magmatic productivity is still debated (e.g. Lundin and Doré, 2005) although we have unsurpassed constraints on conjugate crustal structure between the Norwegian Jan MayenGreenland rifted margins in the northeast Atlantic and the western Greenland margin (Abdelmalak et al., 2019). The controversy centres on three competing hypotheses: (1) excess magmatism resulting from elevated mantle potential temperatures and mantle plume processes, (2) small-scale 


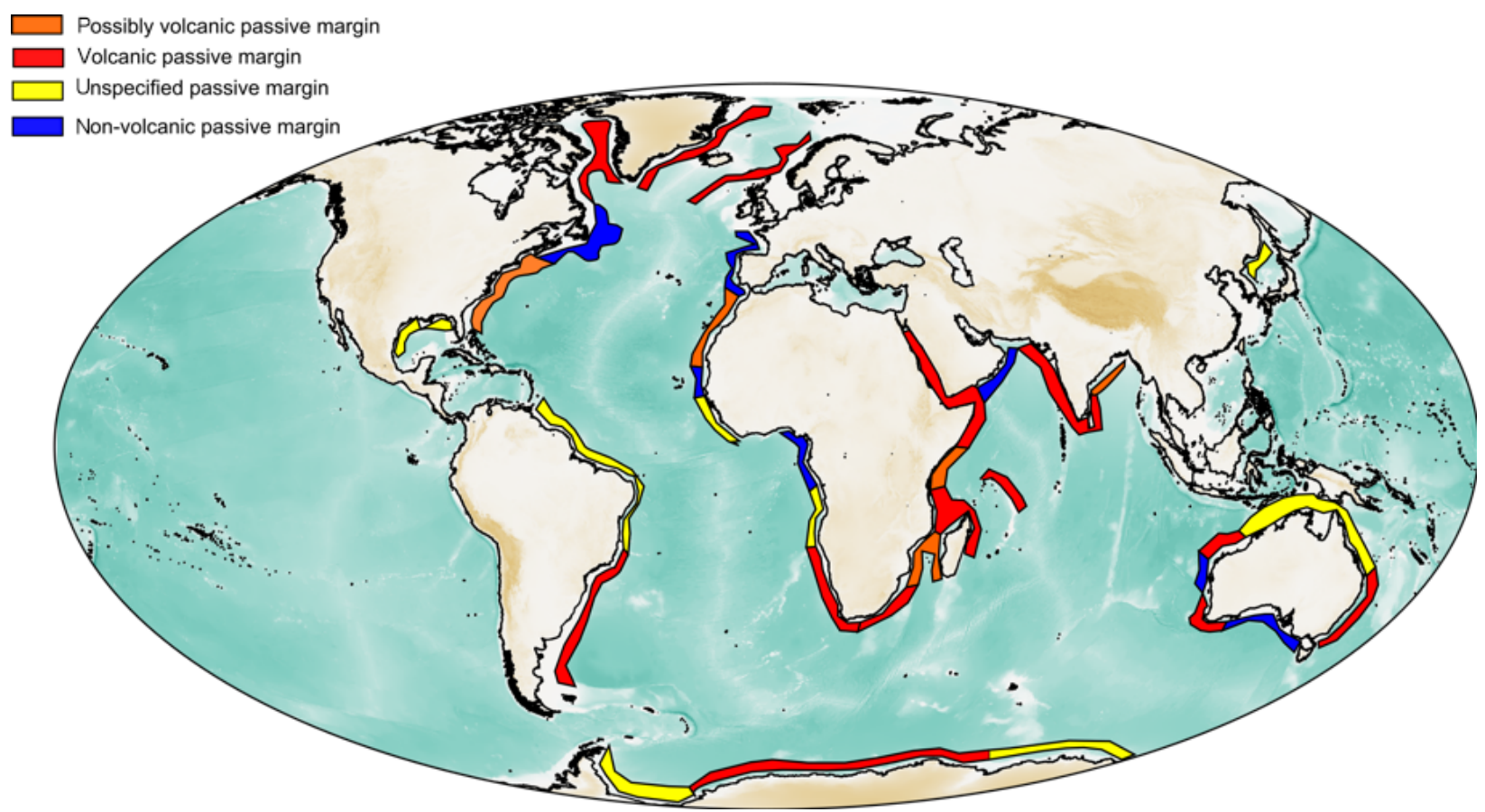

Figure 1. Distribution of the different types of passive margins around the world. The northeast Atlantic rifted margins are the type examples of volcanic rifted margins. Compiled from Menzies et al. (2002), Geoffrey (2005), Haupert et al. (2016), Jones et al. (2016), and Brune et al. (2016).

convection at the base of the lithosphere enhancing the flux of material through the melt window during rifting and midoceanic ridge spreading, and (3) depth-dependent extension with wide margins promoting excess magmatic accretion. Bonatti (1990) proposed an alternative for the formation of excess magmatism based on mantle heterogeneities in addition to these geodynamic end-members. Whereas the mantle plume mechanism requires anomalous high temperatures resulting in high degrees of melting during asthenosphere upwelling, small-scale convection operates without elevated potential temperatures. In contrast small-scale convective instabilities at the base of the lithosphere are inherently connected to and produced by the rifting process (Keen and Boutilier, 2000).

Continental breakup may be associated with extensive volcanism over large distances along the strike of the rifted margins as exemplified in the northeast Atlantic (Fig. 2). The causes for the anomalous magmatic activity and the implications on the palaeoenvironment are, however, still debated. Magmatic products (Fig. 3) emplaced along these volcanic rifted margins have four major characteristics. (1) Wedges of seaward-dipping reflectors (SDRs) and associated volcanic seismic facies units, interpreted as massive sub-aerial and submarine lava flows and volcaniclastic sediments, are found on both sides of the ocean-continent boundary. (2) They have extensive sill and hydrothermal vent complexes emplaced in organic-rich sedimentary basins along the incipient breakup axis. (3) Thick high-velocity bodies in the lower crust along the ocean-continent boundary are commonly interpreted as magmatic underplated material. (4) The magmatic crust at these margins often exceeds $20 \mathrm{~km}$, more than 3 times as thick as normal oceanic crust produced by passive upwelling of the normal potential temperature mantle. It appears that volcanic rifted margins require mantle material that is either (1) anomalously hot, (2) anomalously fertile, (3) actively upwelling at rates higher than the plate half-spreading rate, or some combination of these factors. We propose to test the following hypotheses with the envisioned new IODP drilling campaign.

\subsubsection{Hypothesis 1a: mantle plume involvement produces excess magmatism}

The association of the northeast and northwest Atlantic volcanic rifted margins with the Iceland hotspot has strongly influenced the discussion of the causes for the excess magmatic productivity (e.g. Bijwaard and Spakman, 1999; Ritsema et al., 1999; Foulger et al., 2001; Montelli et al., 2004) and has led to the hypothesis that excessive magmatic productivity, which resulted from high mantle temperatures, was caused by a mantle plume (Brown and Lesher, 2014; McKenzie and Bickle, 1988; White and McKenzie, 1989). Various plume structures have been suggested including (1) a plume head impinging on the base of the lithosphere and (2) rising vertical plume sheets. Numerical models predict that a plume, with a potential temperature of possibly $50-300^{\circ} \mathrm{C}$ higher 


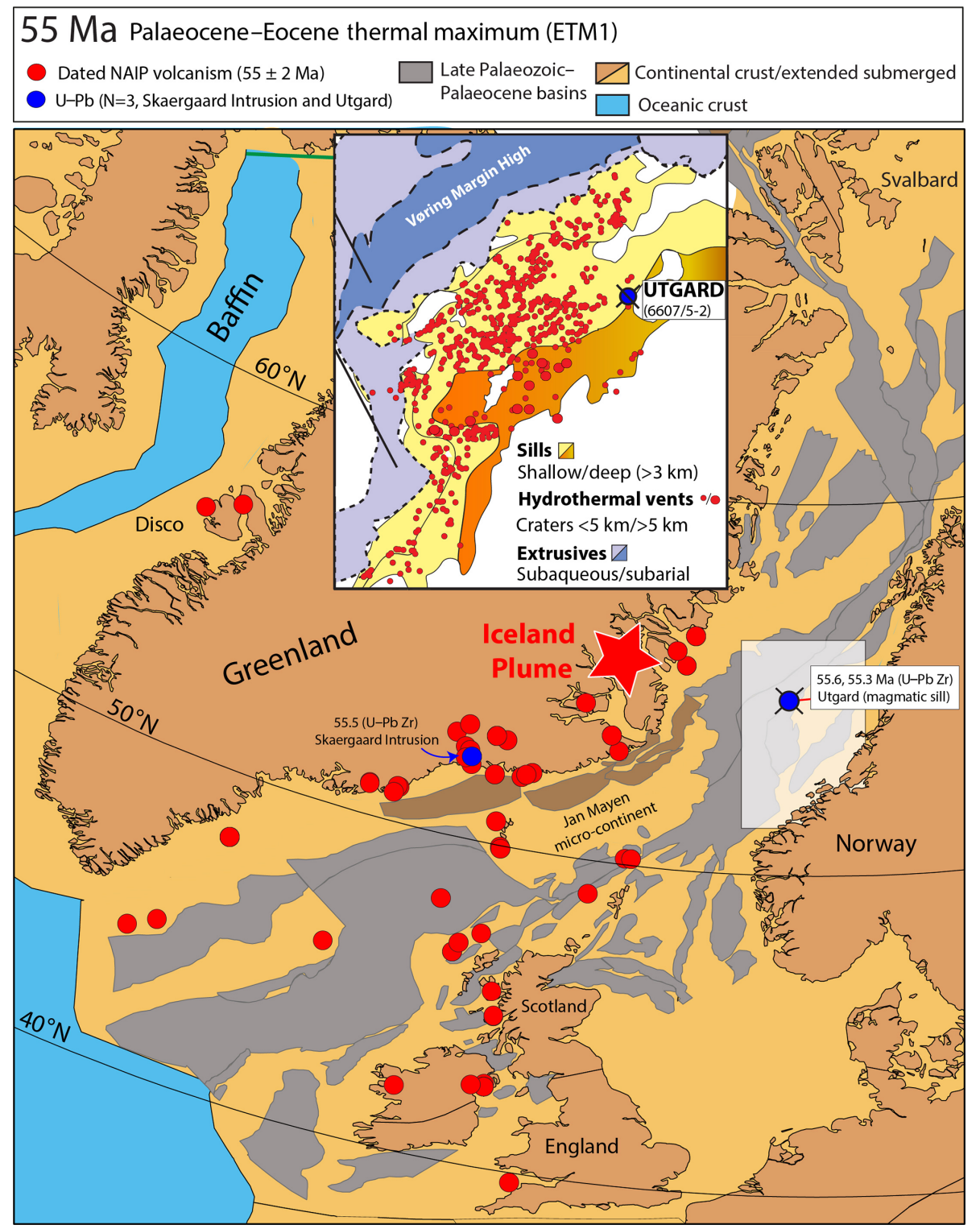

Figure 2. Reconstruction of the northeast Atlantic at $55 \mathrm{Ma}$ with the distribution of dated (57-53 Ma) onshore and offshore sample locations (red filled circles) for the North Atlantic Igneous Province, the location of the Iceland Plume with respect to Greenland (Torsvik et al., 2015), and rift basins developed from the late Palaeozoic to the Palaeocene (Faleide et al., 2010). The inset map demonstrates the extensive sill and hydrothermal vent complexes in the Vøring Basin off the shore of Norway (see white box in main map) and the location of the 6607/5-2 Utgard borehole, where magmatic sills intruding organic-rich sediments are dated to 55.6 and 55.3 Ma (U-Pb zircon; Svensen et al., 2009). From a database of many hundreds of dated volcanics and intrusions there are only six U-Pb ages, ranging from $62.6 \pm 0.6 \mathrm{Ma}$ (Antrim lower basalt in Ireland) to 56.02 Ma (Skaergaard intrusion in eastern Greenland).

than the surrounding mantle, can produce large quantities of melt (White and McKenzie, 1995; Hole and Millett, 2016; McKenzie and Bickle, 1988). Larsen and Saunders (1998) proposed that the opening of the northeast Atlantic rift allowed a sheet of hot plume material to spread along the rift for as much as $2700 \mathrm{~km}$ from south of Greenland to the Barents Sea. Recent seismic tomography confirms that the Iceland anomaly extends to the lower mantle (e.g. French and Romanowicz, 2015; Jenkins et al., 2016).

\subsubsection{Hypothesis $1 \mathrm{~b}$ : active upwelling without a thermal anomaly}

Active mantle upwelling without a thermal anomaly provides an alternative mechanism for excess magmatism at volcanic rifted margins involves. Active upwelling is defined as upwelling of mantle at a rate higher than the half spreading rate of the rift zone (Holbrook and Kelemen, 1993). Mutter et al. (1988) first suggested that small-scale convection induced 


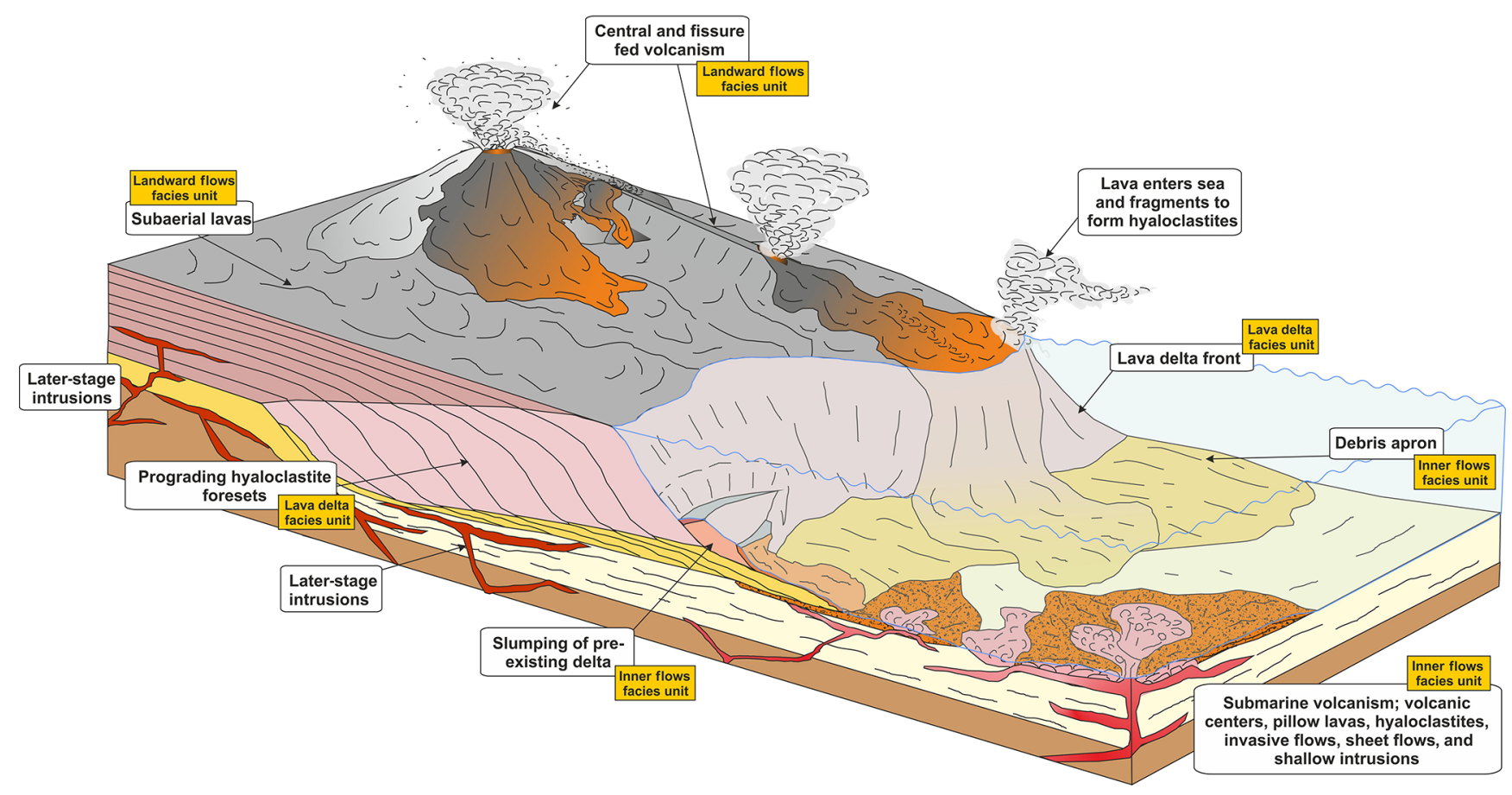

Figure 3. Breakup volcanism in the North Atlantic resulted in extrusion (pink and orange colours) and intrusions (red) of magmas into the sediments basins and led to the development of lower crustal bodies with particularly high seismic velocities called underplating (not shown) (Abdelmalak et al., 2016).

by lateral temperature gradients may provide an enhanced flux of material into the region of partial melting, thereby increasing magmatic activity in the absence of mantle potential temperatures elevated by an external influence. While this hypothesis has attracted considerable attention (Mutter et al., 1988; Boutilier and Keen, 1999; Keen and Boutilier, 2000; Nielsen and Hopper, 2004; Simon et al., 2009), the relative importance of active upwelling in the evolution of rifted volcanic margins is still debated (Holbrook et al., 2001; Korenaga et al., 2000, 2002).

\subsubsection{Hypothesis 1c: excess magmatism owing to an enriched mantle source}

Major element source heterogeneity may also contribute to anomalously high melt production during continental breakup (Davies, 1983; Zindler et al., 1984; Allègre and Turcotte, 1986; Allègre and Lewin, 1995; Morgan and Morgan, 1999; Kellogg et al., 2002; Meibom and Anderson, 2004; Albarède, 2005). The mantle is characterised by significant chemical and isotopic heterogeneity and appears to be a heterogeneous assemblage of depleted and enriched peridotite, as well as recycled subducted oceanic crust, the lithosphere, and sediments. Inherited enriched domains in the sub-lithospheric mantle with anomalously low melt temperatures may therefore deliver more melt during their ascent beneath the extending lithosphere and at the ridge axis.
These end-member processes have distinct characteristics and diagnostic features that may be used to differentiate their relative roles during volcanic margin formation. Plume-related anomalous high mantle temperatures will result in high melt fractions, high-pressure melting, and distinct geochemical characteristics (e.g. He and $\mathrm{Sr}-\mathrm{Nd}$ isotope anomalies). Active upwelling (small-scale convection), conversely, without a thermal anomaly will result in a low average pressure of melting (Holbrook et al., 2001; Korenaga et al., 2002), low degrees of melting, and geochemical signatures closer to mid-ocean ridge basalt (MORB). Furthermore, the plume mechanism predicts that the largest excess magmatic productivity will occur close to the plume centre and there will be local structural control on melting. Active upwelling caused by small-scale convection on the contrary is completely controlled by the local geometry of rifting, its consequences for local perturbations in thermal structure, and the local viscosity and density structure of the mantle lithosphere and sub-lithospheric mantle. A fertile source should result in a high average pressure of melting and distinct isotope geochemistry of the melts indicating an enriched source. Information on the temporal and spatial variations of the mantle potential temperature and active upwelling can be used to constrain models of rift dynamics, rift-related convection, and plume-rift interaction (Brown and Lesher, 2014). 
In spite of 30 years of research into the reasons for excess magmatism during the breakup of continents, it has not been possible to determine which of the three competing hypotheses $(1 \mathrm{a}-1 \mathrm{c})$ is correct. Therefore, we propose a new approach to test the hypotheses that goes beyond the largely geochemical approaches that have been employed in the past. By drilling the various breakup related volcanic facies units, we will produce the information on the timing, the rates of volcanism, and the vertical movements of the Norwegian margin necessary to feed geodynamic models that are able to distinguish between the competing hypotheses.

We concluded during the workshop by affirming that it is important to test a further hypothesis that will deal with the consequences of breakup magmatism.

\subsubsection{Hypothesis 2: voluminous emplacement of magma in organic-rich sedimentary basins and basaltic eruptions may trigger global warming}

The magma volume, eruption duration, and emplacement environment are critical parameters for the palaeoenvironmental implications of LIPs. Svensen et al. (2004) proposed a new hypothesis to explain how LIPs could trigger global environmental crises. The basic feature of this hypothesis is that magma emplaced into organic-rich sedimentary sequences leads to heating of the host rock and generation of large volumes of greenhouse gases, most importantly $\mathrm{CH}_{4}$ and $\mathrm{CO}_{2}$ (Aarnes et al., 2010, 2011). The gas generation may cause an overpressure build-up and formation of so-called hydrothermal vent complexes (Svensen et al., 2004; Reynolds et al., 2017), releasing fluids and sediments to the hydrosphere and atmosphere (Aarnes et al., 2015). This hypothesis may be tested by collecting climate proxy data and sampling proximal Palaeocene-Eocene deposits both in the Vøring Basin and in Denmark (e.g. Svensen et al., 2004; Frieling et al., 2016). The proximal nature of the Vøring Basin to the volcanic and magmatic sequences of the North Atlantic Igneous Province (NAIP) could allow for the differentiation between volcanic and thermogenic origins of gases, as differences between sub-aerial and subaqueous emissions of key magmatic tracers such as tephra and mercury have a primary control on their subsequent dispersal (Jones et al., 2019). Comparisons of this proximal dataset with distal sedimentary systems would then offer insights into the relative timing of extrusive and intrusive magmatic activity and its temporal relationship to climate change events. The sedimentary record may also provide insight into the long-term Palaeocene climate variation in a proximal setting during the early phase of the NAIP and potential palaeoclimate links to basaltic explosive and effusive eruptions.

\subsection{Effects of volcanism on climate change}

Volcanoes play a key role in many global element cycles, helping to replenish and regulate atmospheric and oceanic chemistry over time. However, volcanism is episodic and stochastic in nature, and elevated periods of activity in Earth history will impact the carbon cycle (Jones et al., 2016). Periods of elevated volcanism such as the emplacement of the NAIP often coincide with considerable environmental perturbations such as the PETM (Fig. 4), suggesting a possible causal relationship (Bond and Wignall, 2014). The total volume of magma emplaced during the Paleogene is estimated to be $6-10 \times 10^{6} \mathrm{~km}^{3}$ (Saunders et al., 2007). NAIP activity is interpreted as occurring in two main pulses of activity:

1. A pre-breakup phase of continental flood basalt volcanism was largely erupted through and onto continental crust.

2. The main, more-voluminous phase of thick lava flows and widespread intrusions is closely associated with the breakup of the northeast Atlantic Ocean (Saunders et al., 2007; Storey et al., 2007b; White and McKenzie, 1995).

The formation of the NAIP delivered considerable volumes of greenhouse gases to the atmosphere, both in the form of direct volcanic degassing and explosive discharge of thermogenic gases generated by contact metamorphism around magma intrusions into sedimentary basins (Svensen et al., 2004). Therefore, the NAIP is one of the primary contenders for causing the steady warming and, potentially, also numerous hyperthermal events in the Paleogene (e.g. Cramer et al., 2003; Lourens et al., 2005), either by direct forcing and/or as an instigator of positive climate feedbacks such as methane hydrate melting (e.g. Lunt et al., 2011).

The relationship between the NAIP and Paleogene climate remain a topic of intense debate. The extreme greenhouse conditions of the PETM occurred at ca. 55.8 Ma (Charles et al., 2011), which coincides with the second major pulse of activity from the NAIP (Storey et al., 2007a). However, there are significant gaps in our understanding of the timing and volumes of greenhouse gas fluxes from both volcanic and intrusive NAIP activity. A robust geochronology of the NAIP activity is currently hindered by the limited number of accurate radiometric ages and relatively limited ability to trace LIP volcanism in sedimentary archives. At present, the available modern geochronological data are restricted to ${ }^{40} \mathrm{Ar} /{ }^{39} \mathrm{Ar}$ mineral ages and a few U-Pb ages for subvolcanic intrusions (Larsen et al., 2016; Storey et al., 1998, 2007b; Svensen et al., 2010; Wilkinson et al., 2016). Significant hiatuses can be observed in between the two phases of magmatism in the late Palaeocene (Larsen et al., 1999; Storey et al., 2007b), although the apparent timing of these repose periods seems to vary across the NAIP. In eastern Greenland there is corroborating evidence that voluminous volcanism occurred in the late Palaeocene and early Eocene. The initial emplacement of the Skaergaard intrusion occurred at 56.02 Ma (Wotzlaw et al., 2012), and a geobarometer study using amphiboles suggests that the intrusion was buried by $5.3-6.3 \pm 2.7 \mathrm{~km}$ of flood basalts as it crystallised (Larsen and 


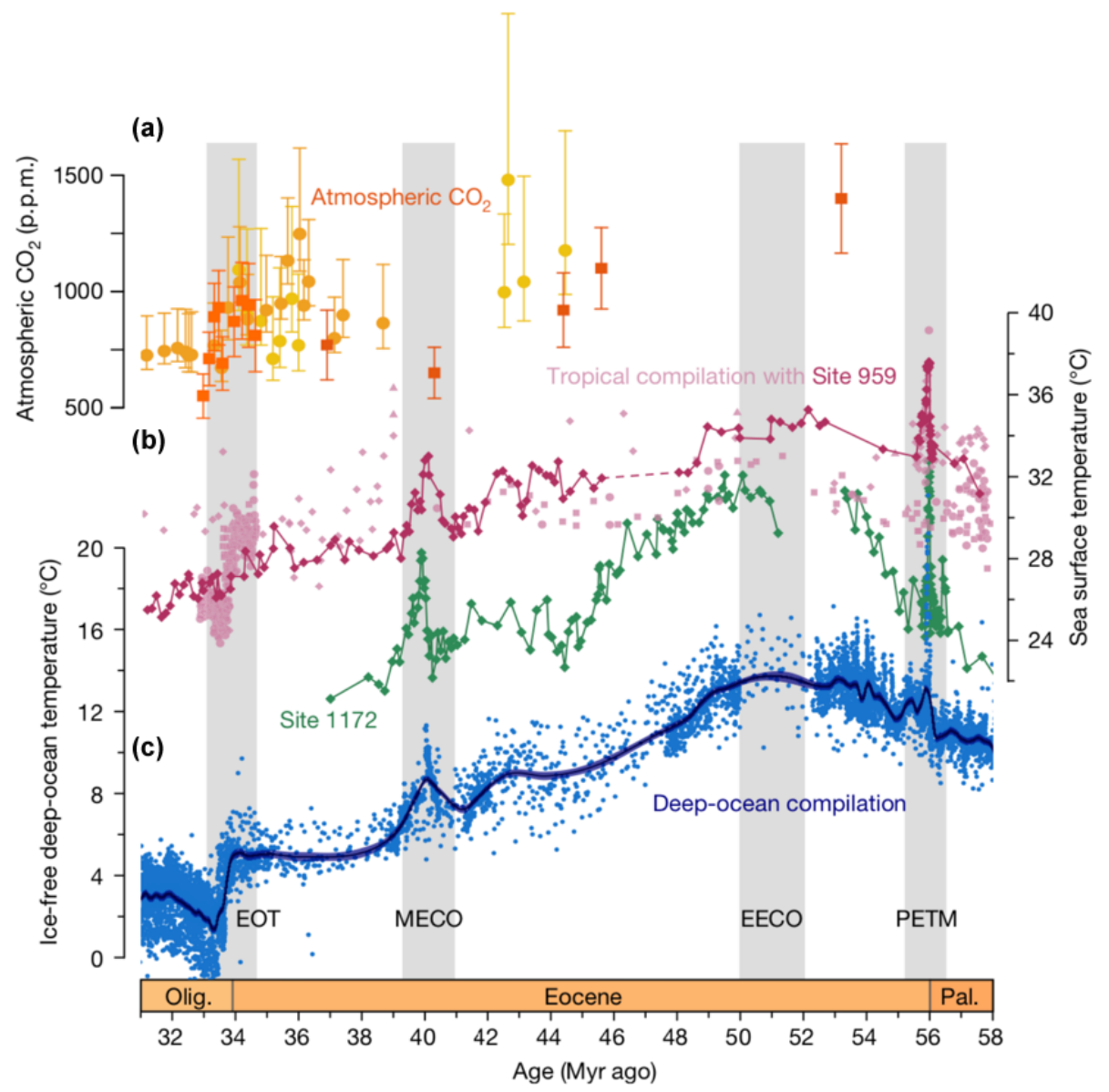

Figure 4. Eocene global climate evolution (redrawn from Cramwinckel et al., 2018). (a) Compiled atmospheric $\mathrm{CO}_{2}$ based on boron isotope and alkenone stable carbon isotope fractionation data. (b) High-latitude (green) and tropical (purple and pink) sea surface temperature records based on organic $\left(\mathrm{TEX}_{86}\right)$ and various carbonate-based $(\mathrm{Mg} / \mathrm{Ca}$, oxygen isotope, and clumped isotopes) inorganic geochemical proxy data. (c) Ice-free deep-ocean temperature based on high-resolution oxygen isotope data of benthic foraminifera.

Tegner, 2006). This estimate equates to around 100-300 kyr, representing a huge outpouring of lava that began $\sim 200 \mathrm{kyr}$ before the PETM (Charles et al., 2011). Moreover, a distinctive tephra layer in the uppermost part of the East Greenland flood basalts (Heister et al., 2001) is indistinguishable in both chemistry and age to a prominent tephra horizon found in the North Sea and in Danish strata (Storey et al., 2007a). The corrected $\mathrm{Ar} / \mathrm{Ar}$ radiometric age is $\sim 55.6 \pm 0.12 \mathrm{Ma}$ for this tephra (Lars Augland, personal communication, 2019), indicating a $400 \mathrm{kyr}$ time interval for the East Greenland flood basalts that encompasses the PETM.

There is also mounting evidence for considerable magmatic intrusions during this time interval. Vent structures form at the edges of sill intrusions due to overpressure generated by pore fluid boiling and/or gas generation from contact metamorphism (Aarnes et al., 2015). The resulting explosions are capable of ejecting gases into the atmosphere, even from submarine vents (Svensen et al., 2004). Many submarine hydrothermal vent complexes have been identified in the Norwegian Sea (Planke et al., 2005), in the Faroe-Shetland basin (Hansen, 2006), and on the northeastern Greenland margin (Reynolds et al., 2017), which suggests that these features were widespread along the proto-northeast Atlantic margins. The majority $(\sim 95 \%)$ of the vent complexes in the Vøring and Møre basins terminate at the horizon between Palaeocene and Eocene strata, with the remainder terminating within the Palaeocene sequence (Planke et al., 2005), with some examples penetrating through earlier volcanic events (Angkasa et al., 2017). The only drilled vent complex is dated to within the PETM (Frieling et al., 2016), whereas a zircon $\mathrm{U}-\mathrm{Pb}$ age from a sill in the Vøring Basin was dated to ca. 55.6 Ma (Svensen et al., 2010). It therefore appears likely that the emplacement of sills led to considerable hydrothermal venting of gases around the time of the PETM.

While both volcanism and contact metamorphism degassing appear to coincide with the global warming events of the late Palaeocene and early Eocene, there remain considerable unknowns in terms of temporal development and potential gas fluxes from these sources. Moreover, it is currently difficult to separate the effects of volcanism and con- 
tact metamorphism in order to assess their relative forcing on the climate system. There are a number of possible ways to improve the geochronology and relative importance of each flux in the Paleogene. The acquisition of core material through continuous strata in close proximity to the NAIP would be an invaluable asset in deciphering the relative importance of these two processes. While both volcanism and contact metamorphism release greenhouse gases, gases from the latter are partly produced from sedimentary organic matter and therefore have much more depleted $\delta^{13} \mathrm{C}$ values. The eruptions from hydrothermal vent complexes are also more likely to transfer co-erupted metals such as mercury to the overlying water column, so large variations in metal concentrations in sediments proximal to vent complexes would suggest periods of elevated degassing driven by sill intrusions (Jones et al., 2019).

\section{North Atlantic Igneous Province}

While many continental margins may be considered volcanic rifted margins (e.g. South Atlantic, Arabian Sea, and northwestern Australia) the northeast Atlantic is by far the most intensely studied volcanic rifted margin. As an early frontier for hydrocarbon exploration this margin attracted also scientific attention and for the past seven decades an enormous amount of geophysical and drilling data were collected culminating in five DSDP and ODP legs: Leg 38 (1974) Vøring (Talwani and Eldholm, 1977); Leg 81 (1981) - Rockall (Roberts et al. 1984); Leg 104 (1985) - Vøring (Eldholm et al. 1987, 1989); Leg 152 (1993) - southeastern Greenland (Larsen et al. 1994; Larsen and Saunders, 1998); Leg 163 (1995) - southeastern Greenland (Larsen et al., 1999; Duncan et al., 1996). Apart from the enormous amount of available data and a priori information, the North Atlantic Igneous Province also lends itself to the study of breakup volcanic processes because both conjugate margins can still be studied and because rifting occurred over a wide area trapping terrestrial sediments. This results in a situation in which the breakup volcanic successions are nearer to the seafloor than on other volcanic margins, which makes it easier to study them by geophysical methods and drilling.

The northeast Atlantic rift system developed as a result of a series of rift episodes succeeding the Caledonian orogeny that ultimately led to continental breakup and passive margin formation in the Palaeocene-Eocene (e.g. Talwani and Eldholm, 1977; Eldholm et al., 1989; White and McKenzie, 1989; Skogseid et al., 2000). The conjugate Norwegian Jan Mayen-Greenland margins are now very well covered by 2 $\mathrm{D}$ and 3-D reflection and refraction seismic surveys, by potential field and heat flow data, and by borehole data that allow a refined structural and stratigraphic framework (Figs. 1, 2, and 3) (e.g. Gudlagusson et al., 1988; Lundin and Doré, 1997; Brekke, 2000; Raum, 2000; Tsikalas et al., 2001, 2005; Osmundsen et al., 2002; Gernigon et al., 2003; Ren et al.,
2003; Hamann et al., 2005; Mjelde et al., 2005a; Breivik et al., 2006).

The Norwegian margin is segmented along strike by the northwest-trending Jan Mayen Fracture Zone and the Bivrost Lineament, which separate from south to north the Møre, Vøring, Lofoten-Vesterålen, and Barents Sea margin segments on the Norwegian side and their conjugates at the Jan Mayen microcontinent and off of northeastern Greenland (Figs. 1 and 2). Margin segments are characterised by strongly different tectonomagmatic styles and sediment distributions (Fig. 4) (Doré et al., 1999; Berndt et al., 2001; Eldholm et al., 2002). The largest magmatic accumulation is observed in the Vøring segment with decreased volumes to the south and north. In the southern segment, passive margin formation and oceanic spreading were accommodated by the Aegir Ridge between the Møre and Jan Mayen (at the time still connected to Greenland) conjugate margins in the Palaeocene-Eocene. The Aegir Ridge was abandoned in the late Oligocene and the Jan Mayen micro-continent separated from Greenland during the development of the Kolbeinsey Ridge (Talwani and Eldholm, 1977; Nunns, 1982; Skogseid et al., 2000; Müller et al., 2001).

Rifting and passive margin formation in the northeast Atlantic was accompanied by strong volcanic activity (White and McKenzie, 1989; Eldholm et al., 1989; Eldholm and Grue, 1994; Larsen and Saunders, 1998). Along the northeast Atlantic rifted margins, evidence for extensive magmatism is provided by SDRs, magmatic intrusives, and highvelocity bodies at the base of the continental crust underlying the ocean-continent boundary which in the distal margin are unequivocally interpreted as a magmatic underplate (Talwani and Eldholm, 1977; Roberts et al., 1984; Eldholm et al., 1989; Larsen and Saunders, 1998; Berndt et al., 2001; Mjelde et al., 2005b; Planke et al., 2005).

The ODP drilling of the Vøring Margin (Leg 104) and off of southeastern Greenland (Legs 152 and 163) recovered volcanic rock successions that erupted during the initial stages of the opening of the northeast Atlantic (Fig. 5). The drilled rocks (Legs 152 and 163) range from pre-breakup continental tholeiitic flood basalt, through syn-breakup picrite, to oceanic-type basalt that form the main part of the SDRs (Fitton et al., 2000). The oceanic-type lavas show an increasing degree of melting and contribution from asthenospheric mantle sources with time (Fram et al., 1998; Fitton et al., 1998). The thickness of igneous crust accreted at the southeastern Greenland continent-ocean boundary increases from about $18 \mathrm{~km}$ in the south to about $30 \mathrm{~km}$ near the GreenlandIceland Rise (Holbrook et al., 2001). Similarly, geochemical enrichment of volcanics of the East Greenland Margin (e.g. chondrite-normalised $(\mathrm{Ce} / \mathrm{Y})_{\mathrm{N}}$ and isotopes; Fram et al., 1998; Fitton et al., 1998; Tegner et al., 1998; Brown and Lesher, 2014) increases from south to north. The correlation of crustal thickness and compositional enrichment suggests a combination of changes in source composition, source temperature, and/or melting dynamics. It is not known if a sim- 

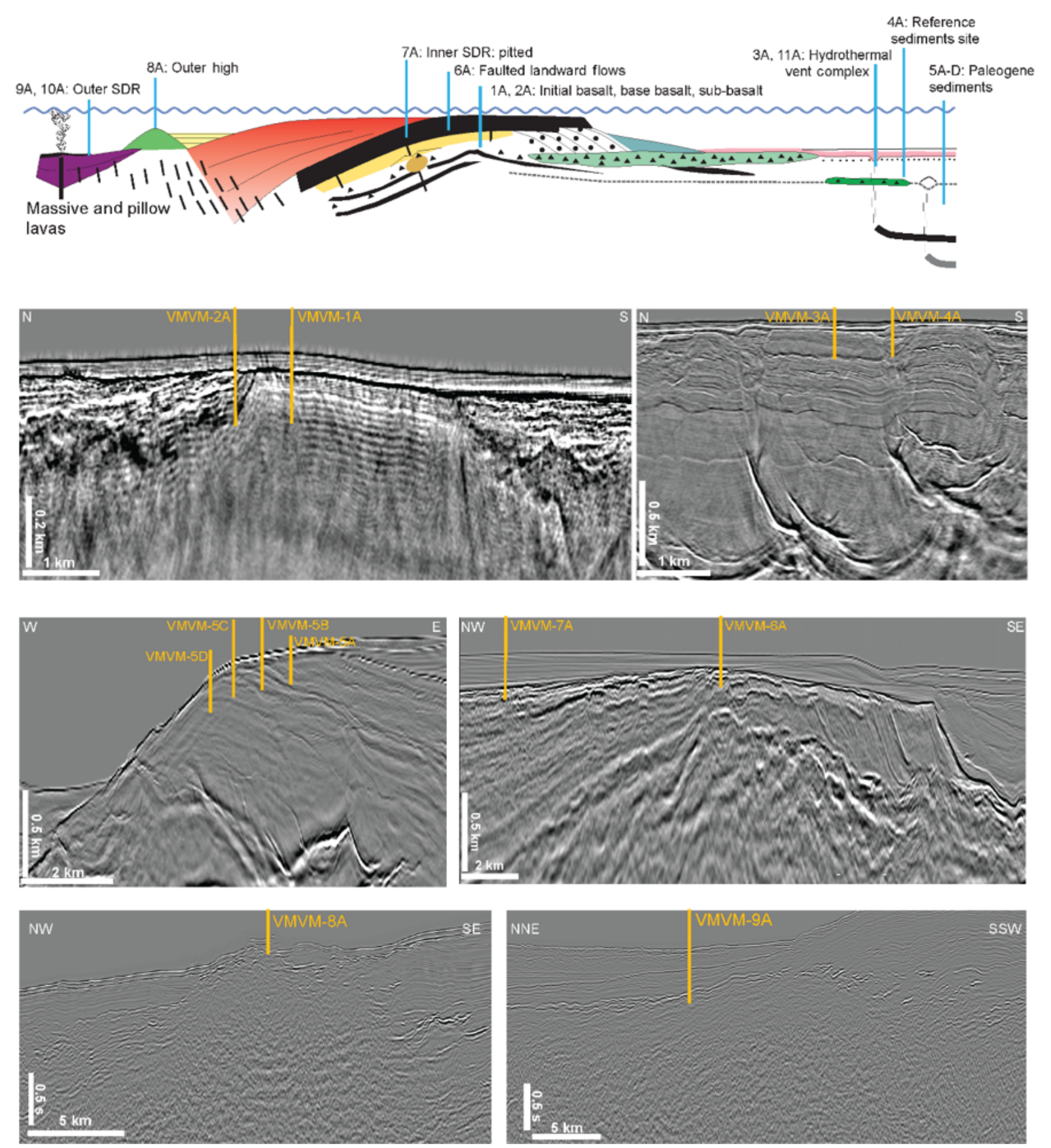

Figure 5. Volcanic seismic facies unit sketch (after Planke et al., 2000) showing schematic location of potential drill sites (top) and modern seismic reflection data showing sites proposed in IODP proposal 944 resulting from the workshop. In sequence (grey panels: left to right, top to bottom) these will test the landward flows, hydrothermal systems linked to sill intrusions, the host rock, the seaward dipping reflectors, the outer high facies, and the outer seaward dipping reflectors (data courtesy of TGS, more information at https://www.tgs.com/, last access: 17 November 2019).

ilar correlation of crustal thicknesses and magma compositions exists along the Norwegian margin. To establish the relationship between the chemistry of the volcanics and crustal configuration would be a milestone of the proposed investigations. Geochemical data (Fig. 5) show strong chemical and isotopic similarities between the "Upper Series" from the
Vøring Plateau and southeastern Greenland. In contrast, the "Lower Series" from both areas are fundamentally different from each other in many aspects. These differences point to substantial differences in either the pre-breakup lithosphere composition at the two localities or to different styles of mantle-crust interaction. 


\section{Drilling strategy and potential sites}

During the workshop discussions focused on a potential drilling strategy to maximise knowledge gain from a new drilling campaign. The mid-Norwegian margin is well suited for scientific drilling of Palaeocene and lower Eocene sequences as the post-breakup sediment cover is thin (commonly less than $200 \mathrm{~m}$ ), and abundant new 2-D and 3-D seismic data exist. The conjugate northeastern Greenland margin and the Jan Mayen Ridge have much thicker post-breakup sediment packages (commonly $1-2 \mathrm{~km}$ ) and regional 2-D seismic coverage, but several deep drilling sites have been identified. Few basement drilling targets were identified in the northwest Atlantic due to kilometre-thick post-breakup sediment units. The Limfjorden region, on the shore of Denmark, is however a promising complementary onshore drilling area, as Palaeocene and lower Eocene sediments and ash layers are outcropping here and accessible for sampling by boreholes of 500-800 m.

On the mid-Norwegian margin the most promising approach would be to drill 5 to 10 shallow holes along one along-strike and one cross-strike margin transect, including volcanic and high-resolution Paleogene sedimentary sites. The temporal and spatial sampling of volcanic rocks is important to constrain melting conditions and plume influence on magmatism. The holes should provide samples of the main volcanic terrains and ages (61-50 Ma). Geochemical data can provide proxy data for the melting temperature and dynamics in space and time. Furthermore, the data can be used to assess mantle heterogeneities, lithospheric structures (e.g. transform margins), and lithospheric contamination. Geochronological data combined with geophysical data are essential to provide constraints on how magma fluxes vary along the strike and across the margin. These are all crucial parameters required to model melting processes.

To determine the relative vertical movement of the margin we propose to test the nature of volcanic seismic facies units. The seismic volcanostratigraphic interpretation suggests that the emplacement environment can be determined from the seismic data (Planke et al., 2000; Berndt et al., 2001; Abdelmalak et al., 2016). Previous drilling on the Vøring Margin (Hole 642E) has documented that the inner SDR and landward flows represent sub-aerially emplaced lava flows. However, to date, no SDR reflections have been drilled by IODP or its predecessors. Furthermore, the nature of the inner flows, lava delta, outer high, and outer SDR has not been documented by scientific boreholes. In the model of Planke et al. (2000) the outer SDRs are emplaced in a deep marine environment; the outer high is in a shallow marine environment; the lava delta is in a coastal environment; and the inner flows are in a deep marine environment. The landward flows, lava delta, and inner flows are thought to represent a transition from the sub-aerial to subaqueous domains (Abdelmalak et al., 2016). The documentation of the emplacement environment of the different facies units will provide important control on the vertical motions of the volcanic eruption centres in space and time, which are important parameters for modelling margin dynamics.

Direct observation of the palaeoenvironment by the sampling of Paleogene sediments will help to determine the relationship between magmatism and the palaeoenvironment. Several potential drilling sites have been identified along the Vøring Transform Margin and on the shore of Denmark. Analyses will include the radiometric dating of tephra layers and collection of volcanic proxy data such as metal enrichments and evidence of hydrothermal vent complex ejecta. These volcanic proxies will be integrated with palynology and organic molecular proxies to reconstruct palaeo-seasurface and palaeo-land-air temperatures and palaeoenvironmental changes.

An across-strike margin transect is proposed in the central Vøring Margin segment, and it could consist of four sites. This transect is located in a typical volcanic rifted margin setting and will cover the entire age range of breakup volcanics to understand syn- and post-breakup volcanism, melting, and margin dynamics. The inner two sites are located on modern 3-D seismic profiles, whereas the outer two sites are located on 2-D seismic profiles. The holes are complementary to the existing DSDP and ODP holes in the region.

The aim of the along-strike transect is to sample volcanic rocks in the northern part of the Møre Margin, the Kolga High. This structure has recently been covered by highquality 3-D industry seismic data, and it documents very thin basalt above a non-reflective structural high. The two sites aim at sampling the sub-basalt and initial basalt deposits on this margin segment. The along-strike profile will include the existing deep ODP 642 Site on the southern Vøring Margin, DSDP Sites, and the two proposed site on the Vøring Marginal High.

Two high-resolution Paleogene sediment sites are proposed along the Vøring Transform Margin. The Paleogene is within the $200 \mathrm{mb}$ b.s. limit in two places, the northern Kolga High and the Mimir High. Two holes are proposed on the northern Kolga High to ensure relatively complete coverage of the sequence. Four slightly offset holes are proposed on the Mimir High. Here, the Palaeocene and lower Eocene sediments are dipping gently northwards and offset drilling may provide a more complete sampling of the succession. In addition, two boreholes in the Limfjorden area, northern Denmark, targeting Palaeocene and lowermost Eocene sedimentary strata and ash layers, are proposed in a complementary ICDP proposal.

\section{Secondary objectives}

\subsection{The role of oceanographic gateways on the onset of Atlantic meridional overturning circulation}

A significant consequence of the tectonic opening of the northeast Atlantic during the Paleogene and Neogene is the 
creation of ocean gateways linking the Arctic Ocean to the Atlantic through the Greenland, Iceland, and Norwegian seas (Nordic Seas). This process has been central to or part of previous scientific drilling expeditions in the northeast Atlantic region, and the results strongly indicate that these connections played a significant role in causing, or amplifying, environmental changes during the Cenozoic through their influence on water mass circulation (Laughton, 1975; Miller and Tucholke, 1983; Jakobsson et al., 2007; Boyle et al., 2017; Coxall et al., 2018; Vahlenkamp et al., 2018). Current questions are focusing again on the role and timing of mantle upwelling beneath Iceland in dynamically supporting regional bathymetry and the depth of oceanic gateways that control the strength of deep-water flow over geologic timescales (Miller and Tucholke, 1983; Poore et al., 2006; Parnell-Turner et al., 2014; Stärz et al., 2017), yet existing records are insufficient to move forward. The recovery of early Cenozoic sediments overlying Palaeocene volcanics on the Vøring Plateau, which are captured impressively in seismic profiles, will provide improved constraints on the evolving oceanic environment of the Nordic seas, especially the transition from non-marine to marine facies. Moreover, we suggest drilling a specified core in the trough "Judd Fall Drift", situated in the Faroe Bank Channel (one of the deep intersections of the Greenland-Scotland Ridge) ( $850 \mathrm{~m}$ water depth; Hohbein et al., 2012). Judd Fall Drift contains a thick sedimentary section (up to $900 \mathrm{~m}$ ) of early middle Eocene to late Miocene (or early Pliocene) sediments and is interpreted from industry seismic evidence to contain a history of Nordic Seas overflow extending back to the middle Eocene (Hohbein et al., 2012). IODP coring of the sequence will be critical for testing this and competing hypothesis about the timing of Greenland-Scotland Ridge subsidence and associated onset of the formation of deep water in the North Atlantic in the early Cenozoic (Via and Thomas, 2006; Hohbein et al., 2012; Boyle et al., 2017; Coxall et al., 2018; Vahlenkamp et al., 2018). These palaeo-ocean gateway objectives will provide an older and more northerly perspective on the links between plume activity and ocean circulation to complement an existing IODP proposal focused on similar questions in the Neogene, i.e. IODP proposal 892 Full (Reykjanes Mantle Convection, Parnell-Turner et al., 2014).

\subsection{Groundwater systems in breakup basalts and carbon storage}

Submarine groundwater discharge is a global phenomenon contributing 3\%-30\% of the fresh water budget in various locations (Taniguchi et al., 2002; Post et al., 2013). In regions covered by glaciers and/or permafrost in the past, the circulation of meteoric water has been shown to relate to a large hydraulic head contrast as a result of the excess weight from glaciers (DeFoor et al., 2011). Signs of meteoric water circulation have been detected from the stable isotopes $\left(\delta^{18} \mathrm{O}\right.$ and $\delta \mathrm{D}$ ) of water from ODP Leg 104 Sites 642 and 643 at the
Vøring Plateau. Such observation is unexpected as these two drill sites are ca. $500 \mathrm{~km}$ from the shelf edge, where the maximum extent of glacier ice was during the Last Glacial Maximum (Patton et al., 2016). Similar signs of meteoric water were also observed along the continental shelf of the Norwegian margin (Egeberg and Aagaard, 1989) and more recently documented by Hong et al. (2019) from the LofotenVesterålen continental slope $(\sim 800 \mathrm{~m}$ water depth and ca. $100 \mathrm{~km}$ from the Lofoten Archipelago). Similar groundwater anomalies were also documented ca. $100 \mathrm{~km}$ southeast of the Greenland shelf (DeFoor et al., 2011).

The presence of meteoric water from the Norwegian and Greenland margins may be associated with the thick basaltic formation as a result of the breakup volcanism in the North Atlantic Ocean. Large-scale basaltic formations serve as quality aquifers at many places around the world. For example, the Columbia River Basalt Group from the western USA, one of the large igneous provinces, is a $163687 \mathrm{~km}^{2}$ aquifer that supplies fresh water to three states (Vaccaro, 1999). In addition to the potential for storing fresh water, basaltic formations are also good candidates for permanent $\mathrm{CO}_{2}$ sequestration. Alteration of basaltic rocks can release calcium ions, which are one of the most essential ingredients for carbonate mineral formation. By injecting solutions into the basaltic formations, the dissolved $\mathrm{CO}_{2}$ can be sequestrated in the formation as carbonate minerals. For example, the investigation of fluid geochemistry around Hekla, Iceland, has shown that the dissolution of basaltic materials can stimulate carbonate mineral precipitation and the drawdown of inorganic carbon content in the solution (Flaathen et al., 2009).

The observations of meteoric water and high dissolved calcium concentrations from the bottom of ODP Sites 642 and 643 have shown that the Vøring Plateau is an ideal place to study the circulation of fresh water within such a large basaltic formation and to assess its potential for $\mathrm{CO}_{2}$ sequestration. However, what was not answered from the early studies is the origin of the meteoric water and the trigger(s) for such large-scale circulation. Furthermore, this will have repercussions on the role of meteoric-water circulation and water-rock interactions on carbon cycling and deep microbial ecosystems. The dating of the water samples from the borehole with tracers such as ${ }^{14} \mathrm{C},{ }^{36} \mathrm{Cl}$, and ${ }^{234} \mathrm{U} /{ }^{238} \mathrm{U}$ (IAEA, 2013) and a systematic analysis of fluid geochemistry (Inagaki et al., 2015) will shed light on some of these questions.

\section{Relationship to the IODP Science Plan for 2013-2023 and beyond}

The breakup of the continents is a fundamental component of the plate tectonic cycle and major episodes of the agglomeration of crustal blocks into supercontinents and their subsequent rifting, and the formation of new oceans has punctuated Earth's evolution since the Archean. Rifting episodes 
result in major changes in the surficial conditions of our planet impacting Earth's atmosphere, climate, ocean circulation and chemistry, and life on land and in the oceans. Some of these events have resulted in the development of the major energy resources that have powered the world's economies for the past century. Consequently, the mechanisms and consequences of continental breakup and the nature of the still poorly defined transitions from continents to oceanic crust have been important targets for scientific ocean drilling since its inception in the Deep Sea Drilling Project 50 years ago.

The current phase of ocean drilling, the International Ocean Discovery Program, is guided by the communityderived science plan Illuminating Earth's past, present, and future: exploring the Earth under the sea (IODP Science Plan for 2013-2023). This document comprises 14 challenges within four major themes:

- "Climate and ocean change: reading the past, informing the future";

- "Biosphere frontiers: deep life and environmental forcing of evolution";

- "Earth connections: deep processes and their impact on Earth's surface environment"; and

- "Earth in motion: processes and hazards on human time scales".

A number of the challenges can be directly or indirectly related to the magmatic and tectonic processes occurring during continental rifting and the formation of passive margins. These include aspects of the composition, structure, and dynamics of Earth's upper mantle (Challenge 8), how seafloor spreading and mantle melting links to ocean crustal architecture (Challenge 9), and the chemical exchanges between the oceanic crust and seawater (Challenge 10). Continental breakup, whether accompanied by large-scale magmatism or principally tectonic, may have major impacts on global chemical cycles and the elemental and isotopic composition of seawater, but to date these effects remain poorly quantified for either volcanic or non-volcanic margins. Passive margins host major potential hazards from submarine landslides and resulting tsunamis (Challenge 12), offer possibilities for the industrial-scale storage of carbon dioxide (Challenge 13), and the loci for the flow of sub-seafloor fluids and consequent tectonic, thermal, and biogeochemical processes (Challenge 14). Although the climatic drivers and effects of magmatism and igneous sill intrusion on the Norwegian margin remain debated (see Sect. 3.3), the temporal coincidence of magmatism, northeast Atlantic breakup, and the major, geologically short-lived, carbon isotopic excursion of the PETM indicate that the sedimentary sequences bordering the northeast Atlantic margins are compelling targets to test models of sedimentary or igneous gas release, gas hydrate de-stabilisation, or thermogenic methane production during contact metamorphism. Direct, sub-seafloor ob- servations of purported gas escape structures may be of direct relevance to anthropogenic-scale industrial carbon dioxide storage. These geological records could directly address ongoing scientific debates regarding the Earth's response to elevated atmospheric $p \mathrm{CO}_{2}$ (Challenge 1) and other greenhouse gases, in particular methane, and the resilience of the oceans to chemical perturbations (Challenge 4). The science plan also includes a number of cross-cutting topics, a number of which can be partly addressed by a campaign of expeditions to the northeast Atlantic region, including hydrocarbon and other resources needed for the 21st century, the calibration of climate models through core observations and analyses, and serpentinisation, which is a major process on some rifted margins.

\section{Conclusions}

The North Atlantic Igneous Province is as thrilling a drilling target as ever. During the MagellanPlus Workshop an impressive amount of new data and ideas were presented. They showed that since the last drilling campaign in 1996 science has moved on, and new industry data do reveal drilling targets that would allow for testing two sets of hypotheses that had not been around for consideration when the last ODP drilling campaign took place. New IODP and ICDP campaigns would lead to a fundamental understanding of the processes that lead to large-scale breakup volcanism and to a better understanding of the consequences that breakup volcanism may have for climate evolution.

\section{Participants of the MagellanPlus Workshop at the GEOMAR Helmholtz Centre for Ocean Research Kiel}

Claire Ansberque (Trinity College Dublin, Ireland), Christian Berndt (GEOMAR, Kiel, Germany), Anett Blischke (Iceland GeoSurvey, Iceland), Christoph Böttner (GEOMAR, Kiel, Germany), Asbjoern Breivik (CEED, University of Oslo, Norway), Susanne Buiter (NGU, Trondheim, Norway), Liwen Chen (GEOMAR, Kiel, Germany), Mike Coffin (University of Tasmania, Australia), Jenny Collier (Imperial College London, UK), Helen Coxall (Stockholm University, Sweden), Gareth Crutchley (GEOMAR, Kiel, Germany), Judith Elger (GEOMAR, Kiel, Germany), Jan Inge Faleide (University of Oslo, Norway), Joost Frieling (Utrecht University, the Netherlands), Dieter Franke (BGR, Hanover, Germany), Jörg Geldmacher (GEOMAR, Kiel, Germany), Laurent Gernigon (Geological Survey of Norway), Ingo Grevemeyer (GEOMAR, Kiel, Germany), Marcus Gutjahr (GEOMAR, Kiel, Germany), Christian Heine (Shell, Amsterdam, the Netherlands), Kaj Hoernle (GEOMAR, Kiel, Germany), Wei-Li Hong (Geological Survey of Norway, Trondheim, Norway), Ritske S. Huismans (University of Bergen, Norway), Anne Jay (The Open University, 
Milton Keynes, UK), Dougal A. Jerram (CEED, University of Oslo, Norway), David Jolley (University of Aberdeen, UK), Morgan Jones (University of Oslo, Norway), Steven M. Jones (University of Birmingham, UK), Jens Karstens (GEOMAR, Kiel, Germany), John Millet (VBPR, UK; University of Aberdeen, UK), Uisdean Nicholson (Heriot-Watt University, Edinburgh, UK), Donald Penman (Yale University, USA), Marta Perez-Gussinye (MARUM, University of Bremen, Germany), Simona Pierdominici (GFZ, Potsdam, Germany), Sverre Planke (VBPR, Norway; University of Oslo, Norway), Lars Rüpke (GEOMAR, Kiel, Germany), Bettina Schramm (GEOMAR, Kiel, Germany), Jakob Skogseid (STATOIL, Oslo, Norway), Damon Teagle (University of Southampton, UK), Christian Tegner (University of Aarhus, Denmark), Trond Torsvik (CEED, University of Oslo, Norway).

Data availability. This contribution is based on previously published data (see references throughout the paper). Seismic data from TGS shown in Fig. 5 were used for illustrative purposes. These data have been uploaded for the safety assessment of the IODP proposal, but they are not publicly available.

Author contributions. CB, SP, and DT organised the workshop. SP, MTJ, and JIF compiled the industry seismic data. TT and JIF summarised the tectonic evolution; RH summarised the melt production; DAJ summarised the volcanic expressions; CT and JF summarised the climate implications; HC summarised the palaeoceanographic setting; and WLH and CB summarised the groundwater system. All authors contributed to the paper.

Competing interests. The authors declare that they have no conflict of interest.

Acknowledgements. The MagellanPlus Workshop was made possible by funding from ECORD and the GEOMAR Helmholtz Centre for Ocean Research Kiel. We thank Jasmin Mögeltönder and Anne Völsch for workshop organisation and logistics. We thank Dan Lizarralde, Sascha Flögel, and an anonymous reviewer for their constructive criticism that has greatly improved the paper and TGS for access to seismic data.

Financial support. This research has been supported by ECORD (grant no. ExNet-0021).

Review statement. This paper was edited by Tomoaki Morishita and reviewed by Daniel Lizarralde, Sascha Flögel, and one anonymous referee.

\section{References}

Aarnes, I., Svensen, H., Connolly, J. A., and Podladchikov, Y. Y.: How contact metamorphism can trigger global climate changes: Modeling gas generation around igneous sills in sedimentary basins, Geochem. Cosmochem. Ac., 74, 7179-7195, 2010.

Aarnes, I., Svensen, H., Polteau, S., and Planke, S.: Contact metamorphic devolatilization of shales in the Karoo Basin, South Africa, and the effects of multiple sill intrusions, Chem. Geol., 281, 181-194, 2011.

Aarnes, I., Planke, S., Trulsvik, M., and Svensen, H.: Contact metamorphism and thermogenic gas generation in the Vøring and Møre basins, offshore Norway, during the Paleocene-Eocene thermal maximum, J. Geol. Soc., 172, 588-598, 2015.

Abdelmalak, M. M., Planke, S., Faleide, J. I., Jerram, D. A., Zastrozhnov, D., Eide, S., and Myklebust, R.: The development of volcanic sequences at rifted margins: New insights from the structure and morphology of the Vøring Escarpment, midNorwegian Margin, J. Geophys. Res., 121, 5212-5236, 2016.

Abdelmalak, M. M., Planke, S., Polteau, S., Hartz, E. H., Faleide, J. I., Tegner, C., Jerram, D. A., Millett, J. M., and Myklebust, R.: Breakup volcanism and plate tectonics in the NW Atlantic, Tectonophysics, 760, 267-296, 2019.

Albarède, F.: The survival of mantle geochemical heterogeneities, American Geophysical Union, Geophys. Monogr. Ser., 160, 27 46, 2005.

Allègre, C. J. and Lewin, E.: Isotopic systems and stirring times of the Earth's mantle, Earth Planet. Sc. Lett., 136, 629-646, 1995.

Allègre, C. J. and Turcotte, D. L.: Implications of a twocomponent marble-cake mantle, Nature, 323, 123-127, https://doi.org/10.1038/323123a0, 1986.

Angkasa, S. S., Jerram, D. A., Millett, J. M., Svensen, H. H., Planke, S., Taylor, R. A., Schofield, S., and Howell, J.: Mafic intrusions, hydrothermal venting, and the basalt-sediment transition: Linking onshore and offshore examples from the North Atlantic igneous province, Interpretation, 5, SK83-SK101, 2017.

Berndt, C., Planke, S., Alvestad, E., Tsikalas, F., and Rasmussen, T.: Seismic volcanostratigraphy of the Norwegian Margin: constraints on tectonomagmatic breakup processes, J. Geol. Soc., 158, 413-426, 2001.

Berndt, C., Hensen, C., Mortera-Gutiérrez, C., Sarkar, S., Geilert, S., Schmidt, M., Liebetrau, V., Kipfer, R., Scholz, F., Doll, M., Muff, S., Karstens, J. Planke, S., Petersen, S., Böttner, C., Chi, W.-C., Moser, M., Behrendt, R., Fiskal, A., Lever, M. A., Su, C.C., Deng, L., Brennwald, M. S., and Lizarralde, D.: Rifting under steam - How rift magmatism triggers methane venting from sedimentary basins, Geology, 44, 767-770, 2016.

Bijwaard, H. and Spakman, W.: Tomographic evidence for a narrow whole mantle plume below Iceland, Earth Planet. Sc. Lett., 166, 121-126, 1999.

Bonatti, E.: Not So Hot Hot-Spots in the Oceanic Mantle, Science, 250, 107-111, 1990.

Bond, D. P. G. and Wignall, P. B.: Large igneous provinces and mass extinctions: An update, Geol. Soc. Am. Spec. Pap., 505, 29-55, 2014.

Boutilier, R. R. and Keen, C. E.: Small-scale convection and divergent plate boundaries, J. Geophys. Res., 104, 7389-7403, 1999.

Boyle, P. R., Romans, B. W., Tucholke, B. E., Norris, R. D., Swift, S. A., and Sexton, P. F.: Cenozoic North Atlantic deep circula- 
tion history recorded in contourite drifts, offshore Newfoundland, Canada, Mar. Geol., 385, 185-203, 2017.

Breivik, A. J., Mjelde, R., Faleide, J. I., and Murai, Y.: Rates of continental breakup magmatism and seafloor spreading in the Norway Basin-Iceland plume interaction, J. Geophys. Res.-Sol. Ea., 111, B07102, https://doi.org/10.1029/2005JB004004, 2006.

Brekke, H.: The tectonic evolution of the Norwegian Sea continental margin, with emphasis on the Vøring and Møre basins, Geol. Soc. Lond. Spec. Pub., 167, 327-378, 2000.

Brown, E. L. and Lesher, C. E.: North Atlantic magmatism controlled by temperature, mantle composition and buoyancy, Nat. Geosci., 7, 820-824, 2014.

Brune, S., Williams, S. E., Butterworth, N. P., and Müller, R. D.: Abrupt plate accelerations shape rifted continental margins, Nature, 536, 201-204, https://doi.org/10.1038/nature18319, 2016.

Charles, A., Condon, D., Harding, I., Pälike, H., Marshall, J., Cui, Y., Kump, L., and Croudace, I.: Constraints on the numerical age of the Paleocene-Eocene boundary, Geochem. Geophy. Geosy., 12, Q0AA17, https://doi.org/10.1029/2010GC003426, 2011.

Coffin, M. F. and Eldholm, O.: Volcanism and continental breakup: a global compilation of large igneous provinces. In Magmatism and the Causes for Continental Breakup, Geol. Soc. Spec. Pub., 68, 17-30, 1992.

Coxall, H. K., Huck, C. E., Huber, M., Lear, C. H., LegardaLisarri, A., O'regan, M., and Backman, J.: Export of nutrient rich Northern Component Water preceded early Oligocene Antarctic glaciation, Nat. Geosci., 11, 190-196, https://doi.org/10.1038/s41561-018-0069-9, 2018.

Cramer, B. S., Wright, J. D., Kent, D. V., and Aubry, M.-P.: Orbital climate forcing of $\delta^{13} \mathrm{C}$ excursions in the late Paleoceneearly Eocene (chrons C24n-C25n), Paleoceanography, 18, 1097, https://doi.org/10.1029/2003PA000909, 2003.

Cramwinckel, M. J., Huber, M., Kocken, I. J., Agnini, C., Bijl, P. K., Bohaty, S. M., Frieling, J., Goldner, A., Hilgen, F. J., Kip, E. L., Peterse, F., van der Ploeg, R., Röhl, U., Schouten, S., and Sluijs, A.: Synchronous tropical and polar temperature evolution in the Eocene, Nature, 559, 382-386, https://doi.org/10.1038/s41586018-0272-2, 2018.

Davies, G. F.: Geophysical and Isotopic evidence for an unlayered, multiple-source mantle, EOS, 64, 175-195, 1983.

DeFoor, W., Person, M., Larsen, H. C., Lizarralde, D., Cohen, D., and Dugan, B.: Ice sheet-derived submarine groundwater discharge on Greenland's continental shelf, Water Resour. Res., 47, W07549, https://doi.org/10.1029/2011WR010536, 2011.

Doré, A. G., Lundin, E. R., Jensen, L. N., Birkeland, Ø., Eliassen, P. E., and Fichler, C.: Principal tectonic events in the evolution of the northwest European Atlantic margin, Geol. Soc. Lond., Petrol. Geol. Conf. Ser., 5, 41-61, 1999.

Duncan, R. A., Larsen, H. C., Allan, J. F., and Shipboard Scientific Party: Proc. ODP, Init. Repts., 163: College Station, TX (Ocean Drilling Program), https://doi.org/10.2973/odp.proc.ir.163.1996, 1996.

Egeberg, P. K. and Aagaard, P.: Origin and evolution of formation waters from oil fields on the Norwegian shelf, Appl. Geochm., 4, 131-142, 1989.

Eldholm, O. and Grue, K.: North Atlantic volcanic margins: dimensions and production rates, J Geophys. Res., 99, 2955-2968, 1994.
Eldholm, O. and Thomas, E.: Environmental impact of volcanic margin formation, Earth Planet. Sc. Lett., 117, 319-329, 1993.

Eldholm, O., Thiede, J., Taylor, E., and Shipboard Scientific Party: Proc. ODP, Init. Repts., 104: College Station, TX (Ocean Drilling Program), https://doi.org/10.2973/odp.proc.ir.104.1987, 1987.

Eldholm, O., Thiede, J., Taylor, E., and Shipboard Scientific Party: Proc. ODP, Sci. Results, 104: College Station, TX (Ocean Drilling Program), https://doi.org/10.2973/odp.proc.sr.104.1989, 1989.

Eldholm, O., Gladczenko, T. P., Skogseid, J., and Planke, S.: Atlantic volcanic margins: a comparative study, Geol. Soc. Lond. Spec. Pub., 167, 411-428, 2000.

Eldholm, O., Tsikalas, F., and Faleide, J. I.: Continental margin off Norway $62-75^{\circ} \mathrm{N}$ : Paleogene tectono-magmatic segmentation and sedimentation, Geol. Soc. Lond. Spec. Pub., 197, 39-68, 2002.

Faleide, J. I., Bjørlykke, K., and Gabrielsen, R. H.: Geology of the Norwegian Continental Shelf, in: Petroleum Geoscience, Springer, Berlin, Heidelberg, Germany, 2010.

Fitton, J. G., Saunders, A. D., Larsen, L. M., Hardarson, B. S., and Norry, M. J. Volcanic rocks from the southeast Greenland Margin at 63N: Composition, petrogenesis, and mantle sources, Proc. ODP Sci. Res., 152, 331-350, 1998.

Fitton, J. G., Larsen, L. M., Saunders, A. D., Hardarson, B. S., and Kempton, P. D.: Paleogene continental to oceanic magmatism on the SE Greenland continental margin at $63 \mathrm{~N}$ : a review of the results of Ocean Drilling Program Legs 152 and 163, J. Petrology, 41, 951-966, 2000.

Flaathen, T. K., Gislason, S. R., Oelkers, E. H., and Sveinbjörnsdóttir, A. E.: Chemical evolution of the Mt. Hekla, Iceland, groundwaters: A natural analogue for $\mathrm{CO}_{2}$ sequestration in basaltic rocks, Appl. Geochem., 24, 463-474, 2009.

Foulger, G. R., Pritchard, M. J., Julian, B. R., Evans, J. R., Allen, R. M., Nolet, G., and Ragnarsson, S.: Seismic tomography shows that upwelling beneath Iceland is confined to the upper mantle, Geophys. J. Int., 146, 504-530, 2001.

Fram, M. S., Lesher, C. E., and Volpe, A. M.: Mantle melting: systematics: transition from continental to oceanic volcanism on the southeast Greenland Margin, Proc. ODP, Sci. Res., 152, 373386, 1998.

French, S. W. and Romanowicz, B.: Broad plumes rooted at the base of the Earth's mantle beneath major hotspots, Nature, 525, 95-98, 2015.

Frieling, J., Svensen, H. H., Planke, S., Cramwinckel, M. J., Selnes, H., and Sluijs, A.: Thermogenic methane release as a cause for the long duration of the PETM, P. Natl. Acad. Sci. USA, 113, 12059-12064, 2016.

Geoffroy, L.: Volcanic passive margin Les marge passives volcaniques, Compt. Rend. Geosci., 337, 1395-1408, 2005.

Gernigon, L., Ringenbach, J. C., Planke, S., Le Gall, B., and Jonquet-Kolst $\varnothing$, H.: Extension, crustal structure and magmatism at the outer Vøring Basin, Norwegian margin, J. Geol. Soc., 160, 197-208, 2003.

Gudlaugsson, S. T., Gunnarsson, K., Sand, M., and Skogseid, J.: Tectonic and volcanic events at the Jan Mayen Ridge microcontinent, Geol. Soc. Lond., Spec. Publ., 39, 85-93, 1988.

Hamann, N. E., Whittaker, R. C., and Stemmerik, L.: Geological development of the Northeast Greenland shelf. In Geol. Soc. Lond., Petrol. Geol. Conf. Ser., 6, 887-902, 2005. 
Hansen, D. M.: The morphology of intrusion-related vent structures and their implications for constraining the timing of intrusive events along the northeast Atlantic margin, J. Geol. Soc., 163, 789-800, 2006.

Haupert, I., Manatschal, G., Decarlis, A., and Unternehr, P.: Upper-plate magma-poor rifted margins: Stratigraphic architecture and structural evolution, Mar. Petrol. Geol., 69, 241-261, https://doi.org/10.1016/j.marpetgeo.2015.10.020, 2016.

Heister, L. E., O’Day, P. A., Brooks, C. K., Neuhoff, P. S., and Bird, D. K.: Pyroclastic deposits within the East Greenland Tertiary flood basalts, J. Geol. Soc., 158, 269-284, 2001.

Hohbein, M. W., Sexton, P. F., and Cartwright, J. A.: Onset of North Atlantic Deep Water production coincident with inception of the Cenozoic global cooling trend, Geology, 40, 255-258, 2012.

Holbrook, W. S. and Kelemen, P. B.: Large igneous province on the US Atlantic margin and implications for magmatism during continental breakup, Nature, 364, 433-436, https://doi.org/10.1038/364433a0, 1993.

Holbrook, W. S., Larsen, H. C., Korenaga, J., Dahl-Jensen, T., Reid, I. D., Kelemen, P. B., and Detrick, R. S.: Mantle thermal structure and active upwelling during continental breakup in the North Atlantic, Earth Planet. Sc. Lett., 190, 251-266, 2001.

Hole, M. J. and Millett, J. M.: Controls of mantle potential temperature and lithospheric thickness on magmatism in the North Atlantic Igneous Province, J. Petrol., 57, 417-436, 2016.

Hong, W. L., Lepland, A., Himmler, T., Kim, J. H., Chand, S., Sahy, D., Solomon, E. A., Rae, J. W., Martma, T., and Nam, S. I.: Discharge of meteoric water in the eastern Norwegian Sea since the last glacial period, Geophys. Res. Lett., 46, 8194-8204, https://doi.org/10.1029/2019GL084237, 2019.

Huismans, R. S. and Beaumont, C.: Depth-dependent extension, two-stage breakup and cratonic underplating at rifted margins, Nature, 473, 74-78, https://doi.org/10.1038/nature09988, 2011.

IAEA: Isotope Methods for Dating Old Groundwater, IAEA Library Cataloguing in Publication Data, International Atomic Energy Agency, Vienna, Austria, 2013.

Inagaki, F., Hinrichs, K.-U., Kubo, Y., Bowles, M. W., Heuer, V. B., Hong, W.-L., Hoshino, T., Ijiri, A., Imachi, H., Ito, M., Kaneko, M., Lever, M. A., Lin, Y.-S., Methé, B. A., Morita, S., Morono, Y., Tanikawa, W., Bihan, M., Bowden, S. A., Elvert, M., Glombitza, C., Gross, D., Harrington, G. J., Hori, T., Li, K., Limmer, D., Liu, C.-H., Murayama, M., Ohkouchi, N., Ono, S., Park, Y.-S., Phillips, S. C., Prieto-Mollar, X., Purkey, M., Riedinger, N., Sanada, Y., Sauvage, J., Snyder, G., Susilawati, R., Takano, Y., Tasumi, E., Terada, T., Tomaru, H., Trembath-Reichert, E., Wang, D. T., and Yamada, Y.: Exploring deep microbial life in coal-bearing sediment down to $\sim 2.5 \mathrm{~km}$ below the ocean floor, Science, 349, 420-424, https://doi.org/10.1126/science.aaa6882, 2015.

Jakobsson, M., Backman, J., Rudels, B., Nycander, J., Frank, M., Mayer, L., Jokat, W., Sangiori, F., O'Reagan, M., Brinkhuis, H., King, J., and Moran, K.: The early Miocene onset of a ventilated circulation regime in the Arctic Ocean, Nature, 447, 986-990, https://doi.org/10.1038/nature05924, 2007.

Jenkins, J., Cottaar, S., White, R. S., and Deuss, A.: Depressed mantle discontinuities beneath Iceland: Evidence of a garnet controlled 660 km discontinuity?, Earth Planet. Sc. Lett., 433, 159168,2016
Jones, M. T., Jerram, D. A., Svensen, H. H., and Grove, C.: The effects of large igneous provinces on the global carbon and sulphur cycles, Paleogeogr. Paleocl., 441, 4-21, 2016.

Jones, M. T., Percival, L. M. E., Stokke, E. W., Frieling, J., Mather, T. A., Riber, L., Schubert, B. A., Schultz, B., Tegner, C., Planke, S., and Svensen, H. H.: Mercury anomalies across the Palaeocene-Eocene Thermal Maximum, Clim. Past, 15, 217 236, https://doi.org/10.5194/cp-15-217-2019, 2019.

Keen, C. E. and Boutilier, R. R.: Interaction of rifting and hot horizontal plume sheets at volcanic margins, J. Geophys. Res., 105, 13375-13387, 2000.

Kellogg, J. B., Jacobsen, S. B., and O'Connell, R. J.: Modeling the distribution of isotopic ratios in geochemical reservoirs, Earth Planet. Sc. Lett., 204, 183-202, 2002.

Korenaga, J., Holbrook, W. S., Kent, G. M., Kelemen, P. B., Detrick, R. S., Larsen, H. C., and Dahl Jensen, T.: Crustal structure of the southeast Greenland margin from joint refraction and reflection seismic tomography, J. Geophys. Res., 105, 21591-21614, 2000.

Korenaga, J., Kelemen, P. B., and Holbrook, W. S.: Methods for resolving the origin of large igneous provinces from crustal seismology, J. Geophys. Res., 107, 2178, https://doi.org/10.1029/2001JB001030, 2002.

Larsen, H. C. and Saunders, A. D.: Tectonism and volcanism at the Southeast Greenland rifted margin: a record of plume impact and later continental rupture, Proc. ODP, Sci. Res., 152, 503-533, 1998.

Larsen, H. C., Saunders, A. D., Clift, P. D., and the Shipboard Scientific Party: Introduction: breakup of the southeast Greenland margin and the formation of the Irminger Basin: background and scientific objectives, in: Proc. ODP, Init. Repts. College Station, TX (Ocean Drilling Program), 152, 5-16, https://doi.org/10.2973/odp.proc.ir.152.101.1994, 1994.

Larsen, L., Waagstein, R., Pedersen, A., and Storey, M.: TransAtlantic correlation of the Paleogene volcanic successions in the Faeroe Islands and East Greenland, J. Geol. Soc., 156, 10811095, 1999.

Larsen, L., Pedersen, A., Tegner, C., Duncan, R., Hald, N., and Larsen, J.: Age of Tertiary volcanic rocks on the West Greenland continental margin: volcanic evolution and event correlation to other parts of the North Atlantic Igneous Province, Geol. Mag., 153, 487-511, 2016.

Larsen, R. B. and Tegner, C.: Pressure conditions for the solidification of the Skaergaard intrusion: Eruption of East Greenland flood basalts in less than 300000 years, Lithos, 92, 181-197, 2006.

Laughton, A. S.: Tectonic evolution of the northeast Atlantic Ocean; a review, Norg. Geol. Unders. B., 316, 169-193, 1975.

Lourens, L. J., Sluijs, A., Kroon, D., Zachos, J. C., Thomas, E., Röhl, U., Bowles, J., and Raffi, I.: Astronomical pacing of late Palaeocene to early Eocene global warming events, Nature, 435, 1083-1087, https://doi.org/10.1038/nature03814, 2005.

Lundin, E. R. and Doré, A. G.: A tectonic model for the Norwegian passive margin withimplications for the northeast Atlantic: Early Cretaceous to breakup, J. Geol. Soc., 154, 545-550, 1997.

Lundin, E. R. and Doré, A. G.: Northeast Atlantic breakup: a reexamination of the Iceland mantle plume model and the AtlanticArctic linkage, Geol. Soc. Lond., Petrol. Geol. Conf. Ser., 6, 739754, 2005. 
Lunt, D. J., Ridgwell, A., Sluijs, A., Zachos, J., Hunter, S., and Haywood, A.: A model for orbital pacing of methane hydrate destabilization during the Paleogene, Nat. Geosci., 4, 775-778, https://doi.org/10.1038/ngeo1266, 2011.

McKenzie, D. and Bickle, M. J.: The Volume and Composition of Melt Generated by Extension of the Lithosphere, J. Petrol., 29, 625-679, 1988.

Meibom, A. and Anderson, D. L.: The statistical upper mantle assemblage, Earth Planet. Sc. Lett., 217, 123-139, 2004.

Menzies, M., Klemperer, S. L., Ebinger, C. J., and Baker, J. A.: Characteristics of volcanic rifted margins, Geol. Soc. Am. Spec. Pap., 362, 1-14, 2002.

Miller, K. G. and Tucholke, B. E.: Development of Cenozoic abyssal circulation south of the Greenland-Scotland Ridge. In Structure and development of the Greenland-Scotland Ridge, Springer, Boston, MA, USA, 549-589, 1983.

Minshull, T. A., Marín-Moreno, H., Armstrong McKay, D. I., and Wilson, P. A.: Mechanistic insights into a hydrate contribution to the Paleocene-Eocene carbon cycle perturbation from coupled thermohydraulic simulations, Geophys. Res. Lett., 43, 86378644, 2016.

Mjelde, R., Raum, T., Breivik, A., Shimamura, H., Murai, Y., Takanami, T., and Faleide, J. I.: Crustal structure of the Vøring Margin,northeast Atlantic: a review of geological implications based on recent OBS data, Geol. Soc. Lond., Petrol. Geol. Conf. Ser., 6, 803-813, 2005a.

Mjelde, R., Raum, T., Myhren, B., Shimamura, H., Murai, Y., Takanami, T., Karpuz, R., and Næss, U.: Continentocean transition on the Vøring Plateau, northeast Atlantic, derived from densely sampled ocean bottom seismometer data, J. Geophys. Res.-Sol. Ea., 110, B05101, https://doi.org/10.1029/2004JB003026, 2005b.

Montelli, R., Nolet, G., Dahlen, F. A., Masters, G., Engdahl, E. R., and Hung, S. H.: Finite frequency tomography reveals a variety of plumes in the mantle, Science, 303, 338-343, 2004.

Morgan, J. P. and Morgan, W. J.: Two-stage melting and the geochemical evolution of the mantle: a recipe for mantle plumpudding, Earth Planet. Sc. Lett., 170, 215-239, 1999.

Müller, R. D., Gaina, C., Roest, W. R., and Hansen, D. L.: A recipe for microcontinent formation, Geology, 29, 203-206, 2001.

Mutter, J. C., Buck, W. R., and Zehnder, C. M.: Convective partial melting: 1. A model for theformation of thick basaltic sequences during the initiation of spreading, J. Geophys. Res., 93, 10311048, 1988.

Nielsen, T. K. and Hopper, J. R.: From rift to drift: Mantle melting during continental breakup, Geochem. Geophy. Geosy., 5, Q07003, https://doi.org/10.1029/2003GC000662, 2004.

Nunns, A.: The Structure and Evolution of the Jan Mayen Ridge and Surrounding Regions: Rifted Margins: Field Investigations of Margin Structure and Stratigraphy. Studies in Continental Margin Geology, AAPG Special Volumes, Pub. Id: A110, 1982.

Osmundsen, P. T., Sommaruga, A., Skilbrei, J. R., and Olesen, O.: Deep structure of the Mid Norway rifted margin, Norw. J. Geol., 82, 205-224, 2002.

Parnell-Turner, R., White, N., Henstock, T., Murton, B., Maclennan, J., and Jones, S. M.: Acontinuous 55-million-year record of transient mantle plume activity beneath Iceland, Nat. Geosci., 7, 914-919, https://doi.org/10.1038/ngeo2281, 2014.
Patton, H., Hubbard, A., Andreassen, K., Winsborrow, M., and Stroeven, A. P.: The build-up, configuration, and dynamical sensitivity of the Eurasian ice-sheet complex to Late Weichselian climatic and oceanic forcing, Quarternary Sci. Rev., 153, 97-121, 2016.

Planke, S., Symonds, P. A., Alvestad, E., and Skogseid, J.: Seismic volcanostratigraphy of large-volume basaltic extrusive complexes on rifted margins, J. Geophys. Res., 105, 19335-19351, 2000.

Planke, S., Rasmussen, T., Rey, S., and Myklebust, R.: Seismic characteristics and distribution of volcanic intrusions and hydrothermal vent complexes in the Vøring and Møre basins, Geol. Soc. Lond., Petrol. Geol. Conf. Ser., 6, 833-844, 2005.

Planke, S., Millett, J. M., Maharjan, D., Jerram, D. A., and Abdelmalak, M. M.: Igneous seismic geomorphology of buried lava fields and coastal escarpments on the Vøring volcanic rifted margin, Interpretation, 5, SK161-SK177, 2017.

Poore, H. R., Samworth, R., White, N. J., Jones, S. M., and McCave, I. N.: Neogene overflow of northern component water at the Greenland-Scotland Ridge, Geochem., Geophy. Geosy., 7, Q06010, https://doi.org/10.1029/2005GC001085, 2006.

Post, V. E., Groen, J., Kooi, H., Person, M., Ge, S., and Edmunds, W.M.: Offshore fresh groundwater reserves as a global phenomenon, Nature, 504, 71-78, 2013.

Raum, T.: Crustal structure and evolution of the Faeroe, Møre and Vøring margins from wide-angle seismic and gravity data, $\mathrm{PhD}$ Thesis, University of Bergen, Bergen, Norway, 2000.

Ren, S., Faleide, J. I., Eldholm, O., Skogseid, J., and Gradstein, F.: Late Cretaceous-Paleocene tectonic development of the NW Vøring basin, Mar. Petrol. Geol., 20, 177-206, 2003.

Reynolds, P., Planke, S., Millett, J. M., Jerram, D. A., Trulsvik, M., and Schofield, N.: Hydrothermal vent complexes offshore Northeast Greenland: A potential role in driving the PETM, Earth Planet. Sc. Lett., 467, 72-78, 2017.

Ritsema, J., van Heijst, H. J., and Woodhouse, J. H.: Complex shear wave velocity structure imaged beneath Africa and Iceland, Science, 286, 1925-1928, 1999.

Roberts, D. G., Schnitker, D., and Shipboard Scientific Party: Init. Rep. DSDP, 81, 701-723, https://doi.org/10.2973/dsdp.proc.81.1984, 1984.

Saunders, A. D., Jones, S. M., Morgan, L. A., Pierce, K., Widdowson, M., and Xu, Y. G.: Regional uplift associated with continental large igneous provinces: The roles of mantle plumes and the lithosphere, Chem. Geol., 241, 282-318, 2007.

Simon, K., Huismans, R. S., and Beaumont, C.: Dynamical modeling of lithospheric extension and small-scale convection: implications for magmatism during the formation of volcanic rifted margins, Geophys. J. Int., 176, 327-350, https://doi.org/10.1111/j.1365-246X.2008.03891.x, 2009.

Skogseid, J., Planke, S., Faleide, J. I., Pedersen, T., Eldholm, O., and Neverdal, F.: Northeast Atlantic continental rifting and volcanic margin formation, Geol. Soc. Lond., Spec. Publ., 167, 295-326, 2000.

Stärz, M., Jokat, W., Knorr, G., and Lohmann, G.: Threshold in North Atlantic-Arctic Oceancirculation controlled by the subsidence of the Greenland-Scotland Ridge, Nat. Commun., 8, 15681, https://doi.org/10.1038/ncomms15681, 2017. 
Storey, M., Duncan, R., Pedersen, A., Larsen, L., and Larsen, H.: ${ }^{40} \mathrm{Ar} /{ }^{39} \mathrm{Ar}$ geochronology of the West Greenland Tertiary volcanic province, Earth Planet. Sc. Lett., 160, 569-586, 1998.

Storey, M., Duncan, R., and Swisher III, C.: Paleocene-Eocene Thermal Maximum and the opening of the Northeast Atlantic, Science, 316, 587-589, 2007a.

Storey, M., Duncan, R., and Tegner, C.: Timing and duration of volcanism in the North Atlantic Igneous Province: Implications for geodynamics and links to the Iceland hotspot, Chem. Geol., 241, 264-281, 2007b.

Svensen, H., Planke, S., Malthe-Sørenssen, Jamtveit, B., Myklebust, R., Rasmussen Eidem, T., and Rey, S.: Release of methane from a volcanic basin as a mechanism for initial Eocene global warming, Nature, 429, 542-545, 2004.

Svensen, H., Planke, S., Chevallier, L., Malthe-Sørenssen, A., Corfu, F., and Jamtveit, B.: Hydrothermal venting of greenhouse gases triggering Early Jurassic global warming, Earth Planet. Sc. Lett., 256, 554-566, 2007.

Svensen, H., Schmidbauer, N., Roscher, M., Stordal, F., and Planke, S.: Contact metamorphism, halocarbons, and environmental crises of the past, Environ. Chem., 6, 466-471, https://doi.org/10.1071/EN09118, 2009.

Svensen, H., Planke, S., and Corfu, F.: Zircon dating tiesnortheastAtlantic sill emplacement to initial Eocene global warming, J. Geol. Soc., 167, 433-436, 2010.

Talwani, M. and Eldholm, O.: Evolution of the Norwegian-Greenland sea, Geol. Soc. Am. Bull., 88, 969-999, https://doi.org/10.1130/00167606(1977)88<969:EOTNS>2.0.CO;2, 1977.

Taniguchi, M., Burnett, W. C., Cable, J. E., and Turner, J. V.: Investigation of submarine groundwater discharge, Hydrol. Process., 16, 2115-2129, 2002.

Tegner, C., Duncan, R. A., Bernstein, S., Brooks, C. K., Bird, D. K., and Storey, M.: ${ }^{40} \mathrm{Ar}^{39} \mathrm{Ar}$ geochronology of Tertiary mafic intrusions along the East Greenland rifted margin: Relation to flood basalts and the Iceland hotspot track, Earth Planet. Sc. Lett., 156, 75-88, 1998.

Torsvik, T. H., Amundsen, H. E. F., Trønnes, R., Doubrovine, P. V., Gaina, C., Kusznir, N. J., Steinberger, B., Corfu, F., Ashwal, L. D., Griffin, W. L., Werner, S. C., and Jamtveit, B.: Continental crust beneath southeast Iceland, P. Natl. Acad. Sci. USA, 112, E1818-E1827, https://doi.org/10.1073/pnas.1423099112, 2015.
Tsikalas, F., Faleide, J. I., and Eldholm, O.: Lateral variations in tectono-magmatic style along the Lofoten-Vesterålen volcanic margin off Norway, Mar. Petrol. Geol., 18, 807-832, 2001.

Tsikalas, F., Eldholm, O., and Faleide, J. I.: Crustal structure of the Lofoten-Vesterålen continental margin, off Norway, Tectonophysics, 404, 151-174, 2005.

Vaccaro, J. J.: Summary of the Columbia Plateau, Regional Aquifersystem Analysis, Washington, Oregon, and Idaho, US Geological Survey, Washington, USA, 1999.

Vahlenkamp, M., Niezgodzki, I., De Vleeschouwer, D., Bickert, T., Harper, D., Turner, S. K., and Pälike, H.: Astronomically paced changes in deep-water circulation in the western North Atlantic during the middle Eocene, Earth Planet. Sc. Lett., 484, 329-340, 2018.

Via, R. K. and Thomas, D. J.: Evolution of Atlantic thermohaline circulation: Early Oligocene onset of deep-water production in the North Atlantic, Geology, 34, 441-444, 2006.

White, R. and McKenzie, D.: Magmatism at Rift Zones - the Generation of Volcanic Continental Margins and Flood Basalts, J. Geophys. Res., 94, 7685-7729, 1989.

White, R. and McKenzie, D.: Mantle plumes and flood basalts, J. Geophys. Res., 100, 17543-17585, 1995.

Wilkinson, C., Ganerød, M., Hendriks, B., and Eide, E.: Compilation and appraisal of geochronological data from the North Atlantic Igneous Province (NAIP), Geol. Soc. Lond., Spec. Publ., 447, 69-103, https://doi.org/10.1144/SP447.10, 2016.

Wotzlaw, J., Bindeman, I., Schaltegger, U., Brooks, C., and Naslund, H.: High-resolution insights into episodes of crystallization, hydrothermal alteration and remelting in the Skaergaard intrusive complex, Earth Planet. Sc. Lett., 355, 199-212, 2012.

Zindler, A., Staudigel, H., and Batiza, R.: Isotope and trace element geochemistry of young Pacific seamounts: implications for the scale of upper mantle heterogeneity, Earth Planet. Sc. Lett., 70, 175-195, 1984. 